\title{
EVOLUTION OF A COASTAL OASIS IN A HIGH POPULATION GROWTH RATE MUNICIPALITY: LOS CABOS, MEXICO
}

\author{
Oscar Arizpe, Judith Juarez, Placido Cruz \& Alberto Torres \\ Autonomous University of South Baja California, Mexico.
}

\begin{abstract}
The San Jose Estuary is an important coastal wetland for the conservation of biodiversity, used for centuries for the local population and tourism, in the Mexican municipality with the highest population growth rate, Los Cabos. This considered coastal oasis has been appointed as State Ecological Reserve (SER), RAMSAR site and area of importance for the conservation of birds. It is also an area of beautiful landscape with the contrast environment arid of the region, by what from makes decades is considered relevant for the sustainability of the city of San Jose del Cabo, being area of recreation of local population, tourism national and international, and for activities of birds watching, just in the center of one of the most important tourist region of Mexico. In this context, the purpose of the study was to develop the social, economic, and environmental characterization of the SER, to approach the knowledge of the status of the system, its evolution in the last two decades and as a basis for the urgent management strategies for the SER. Results to date show a high environmental deterioration, which increasing the vulnerability in the last decade. The polygon of the Natural Protected Area (SER) has changed four times in 20 years, demonstrating that their secular geomorphology has been reduced by more than $40 \%$ in the last 15 years by the unplanned tourism development. This has resulted in a big deterioration that threatens the sustainable development of the contiguous population of San José de el Cabo, increasing the pollution, fires, and finally, a recent decline of tourist interest in the declared also in 2014 as the priority wetland in Baja California Sur, Mexico.

Keywords: coastal oasis, Estuary San Jose del Cabo, natural protected area management, sustainable tourism
\end{abstract}

\section{INTRODUCTION}

The state of Baja California Sur is a privileged geographic region that has a natural value of great relevance both nationally and internationally, to present, among other reasons, the greater coastal extension of the Mexican Republic, also more than $40 \%$ of its area decreed as Protected Natural Area (PNA), and be the one with the greatest diversity of marine resources in Mexico, highlighting the Municipality of Los Cabos by heterogeneous physiography. This region is considered a biogeographic unit distinct from the rest of Mexico, its unique characteristics derived from its geological and natural history, which has allowed the confluence of elements of arid, tropical, and temperate affinity in this region of the country, becoming for this reason is considered as the highlight of tourist places in Mexico.

In the Municipality of Los Cabos, there are five areas for the protection and conservation of natural resources [1]. The Estero San José wetland (ESJ) stands out for its environmental, economic, social, and cultural importance. Tradition and history of its use were coming since the time of the indigenous, called Pericues, which has led it to be considered as of high value for the identity of the community. This ecosystem is of great relevance to the region, both from the water and biological perspective, because it houses unique plant species that are part of important corridors and refuges of flora and fauna, conditions that have generated is also relevant from the Tourism point of view, all of which depends on the proper functionality of the ecosystem. It is also an area of high scenic beauty contrasting with the arid surroundings of the region, generating that for decades, has been a recreation area of local people and 
tourism activities of bird watching, horseback riding and boats. All of this, and the high population growth rate of the region, led to the Decree of San José del Cabo being declared a State Ecological Reserve (REEESJ) on October 8, 1993, published in the official state bulletin on January 10, 1994, with a Surface area of 486.6 ha. On May 24, 2004, the State Government published a new decree of the Reserve, including the increase in the area derived from the sediment supply. On February 24, 2011, the agreement between the Government of the State of Baja California Sur and the City of Los Cabos was signed, so that the latter is responsible for the managing of REEESJ. Finally, in the international sphere, the ESJ is incorporated on February 2, 2008, as an Area of Importance for the Conservation of Birds at the national level under the category G1 and finally in 2009 was registered in the RAMSAR [2] international wetland system.

From 10 years ago, in various forums, it has been mentioned that the study and restoration of the ESJ is urgently needed because it is in the process of deterioration, which was ratified with its analysis and discussion at the recent 'National Forum for Sustainable Coastal Development' (November 2014). Because of this agreement, they were carried out with broad participation of all levels of government, NGOs, academic institutions, and users, with a focus on the entire San José Basin (CSJ). More recently in the years 2015 and 2016, there have been several workshops highlighting that, perhaps, the most important problem is the alteration and the change since 2003 of its geomorphology, generated by the almost complete disappearance of the north arm that borders with Puerto Los Cabos tourism development, which has reduced its stability, increasing the risks of irreversible alteration of the entire riparian ecosystem. Likewise, other adverse factors such as the changes in the area traverse and the change in land use in the boundaries of the natural area polygon due to the urban growth of San José del Cabo city, due to the erosion of the CSJ, have been added. To the impact of human activities (opening of roads, extraction of forest species and livestock), establishing that the magnitude of the effect of all these factors could not be known with existing information, because the baseline information of ecological attributes and integral characterization of the system [3] is outdated from 1996. In this context, the main purpose of this study was to develop the environmental and socioeconomic diagnosis, and the evaluation of the fragility pressure and vulnerability of REEESJC, as basic elements for its management and conservation program.

\section{METHODOLOGY}

The strategy for the diagnosis initially contemplates the bibliographical compilation of the information existing in the area, both the environmental, as well as the economic and social area of influence of the basin and its wetlands. To maintain the integrity and accuracy of the information, a scale of 1: 250,000 was used to generate 1:20,000 scale mapping, data basis with control sites, using orthophotos and/or aerial photography, and high-resolution satellite images. We also collected and analyzed the projects proposed for the area as well as the government programs and actions that can influence it, reviewing the current legal framework that may affect the basin. The information collected was integrated into a Geographic Information System (GIS) for analysis and evaluation. Surveys were also used to collect socioeconomic information related to the assessment of the estuary's environmental services. All information were transformed into a single reference system and universal datum, to facilitate its later spatial analysis in the GIS. The regionalization in environmental units was carried out by GIS overlapping the information in layers, making the corresponding adjustments after the verifications in field of the information used, and with the spatial analysis of 
satellite images and orthophotos. An important aspect to be evaluated was the land use change in the study area, to finally within the GIS environment to obtain the Environmental Units (EU) and regionalization, and later to evaluate their, environmental fragility, human pressure, and finally the total vulnerability. Vulnerability assessment was done with indicators that are important in defining sustainable use and management of environmental resources because they can guide policy formulation by providing valuable information about the current status of resources to be assessed, and of the intensity and direction of possible changes, further emphasizing the primary issues. In this phase, it was necessary to identify the key indicators for each of the products of the diagnosis, for which the first approach was the OECD indicators of Pressure State Response [4] with the adjustments that in the Region context we have studied and developed for the evaluation of the area based on the concept of vulnerability [5-8]. This implies the generation of the following composite indexes (complex indices integrated by other indexes) as an expression of the model: (1). Composite Pressure Index, (2). Composite Index of Fragility, and (3). Composite Index of Vulnerability. We integrated the models of Behrenfeld and Falkowski [9], Thieler and Hammar-Klose [10] Climate Vulnerability Index (IVC), Tallis et al. [11], but the basic model for all the vulnerability assessments for each coastal segment of the REEEESJC is developed by Arizpe et al. [7].

The goal of this phase was to assess vulnerability by estimating the indices and indicators selected in each environmental unit, to design the strategic scenario based on the analysis of the evolution of the physical-biotic, social-demographic, economic-productive, and urbanRegional, based on its main indicators [7]. In this way, the deterioration trends, the reduction of the productive capacity and consequently the potential for the development of the productive activities, as well as the diversity, the ecosystem goods and services were estimated. This regionalized and integrated GIS information will allow key authorities and users not only to perform the wetland maintenance processes in the short term, but also to update the database to integrate such information into the system's management plan and execute the actions identified as relevant as the reduction of pollution, application of regulations, increase water availability, which will favor the coordination of actions of levels of government involved in the wetland and the entire basin. This strategy will also aim to preserve the ecological processes and support systems on which the integrity of the REEESJ depends, to maintain and increase the social and economic benefits of the area, to promote uses that are compatible with the objectives of conservation, exploitation, and in general, the sustainable development of the system and adjacent areas.

The State Ecological Reserve of the Estuary of San José of Cabo (REEESJC) is located in the coordinates $23^{\circ} 05^{\prime} \mathrm{N}$ and $-109^{\circ} 40^{\prime} \mathrm{W}$. Within the REEESJC is the only coastal Baja California freshwater lagoon, bordered to the East and North with the populations of Las Animas, La Playa and La Choya, westward with the big city of San Jose of Cabo, and in the Southeast by the Gulf of California [3] (Fig. 1).

It lies in the hydrographic basin of San José de el Cabo located in the southern part of the Baja California peninsula, has an area of $1,278.5 \mathrm{~km}^{2}$ and borders to the East with the Trinity Sierra and West the Sierra de la Laguna. The main channel of water that feeds the Lake is the arroyo San José, being the basin of San Jose the main source of supply of water for the towns of Cabo San Lucas and San José de el Cabo [12]. This freshwater ecosystem maintains surrounding different plant associations aquatic, underwater, riverside and growing areas, and represents an important area in the migratory route for many birds, which use it as a nesting area after completing their migration. In addition to its beauty and natural components, this 


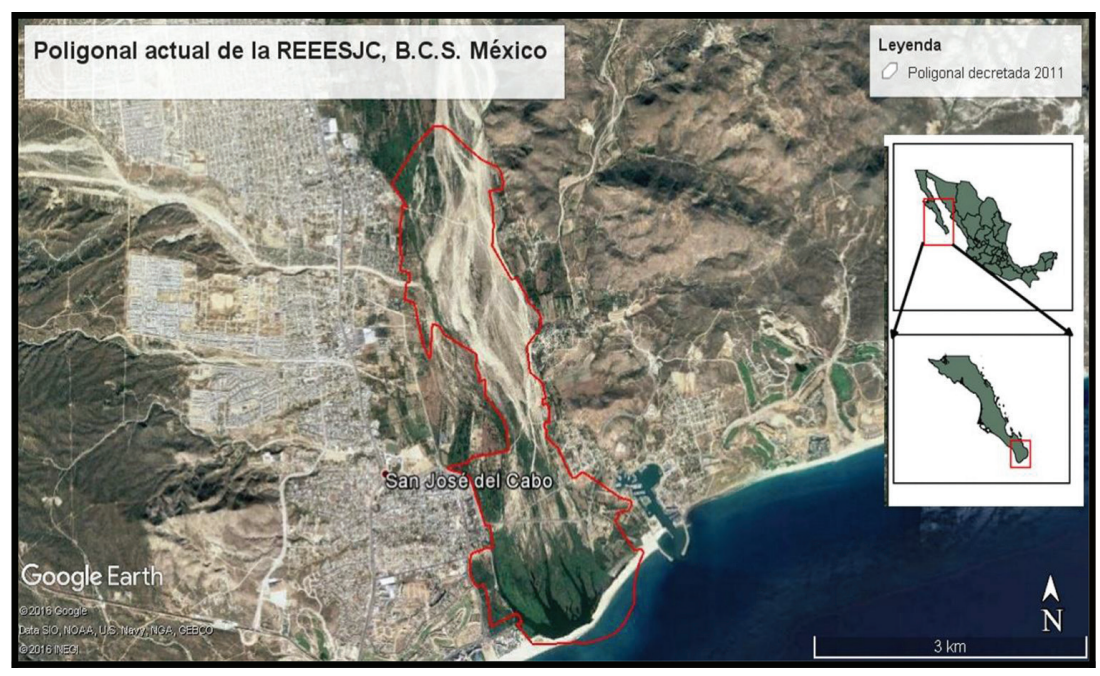

Figure 1: Localization map and recent polygon of the REEESJC.

area has represented from two centuries, an area of recreation for locals, in addition to following it is currently for the urban population that surrounds the system, and the national and international tourism.

The only comprehensive study in an annual cycle in the area is the one done in 1996 [3], however, there are no works focused on the identification, classification and economic valuation of ecosystem services that provides this reserve to the users of the area, as well as the communities adjacent to the REEESJC [12] and [13].

\section{RESULTS}

Diagnosis of the study area was elaborated based on the literature and digital data bases and electronic resources available, some of the documents consulted, refer to the physical and biological characteristics at the basin level $[2,13]$. Others refer to the characteristics of the area at the municipal level (environmental impact assessment (EIA) "works of channeling or protection of watercourses, San Jose in the city of San Jose of the Cape, however, also met specific bibliography [14], which describes specific both biological and physical elements within the study area mainly those related to the body of water, however, the information collected in these works was not referenced or does not correspond to the coordinates that define the current management policies.

In the last 20 years, there have been many changes in the now REEESJC geomorphology, including several amendments in the legal framework in chronological order as follows: on October 8, 1993 is decreed the area of estero de San José de el Cabo as State Ecological Reserve, modifying the January 10, 1994 is category to ecological conservation zone category. In 2004, on the 24th of May, the surface of the polygon is modified again leaving it with a total surface of 512.2 has. April 4th, 2011, again modifying the polygon of the REEESJC staying up to date with a surface of 766.7 has. The main problem evidenced to cause extensive modifications and negative effects in the area is the growth of the human population, which has quadruplicate from 1990 to 2010 (a rate of 455\%) in just 20 years. 
The ecological zoning methodology was applied to specify the comprehensive characterization of system, by sub-region diagnosis and analysis of information, area [7] to generate a spatial reference, allowing you to identify homogeneous units easily recognized, including their problems (environmental units) obeying the new conditions generated by natural phenomena and human activities. A total of 13 environmental units (EU), two of which are formed by two fragments and the rest by a single fragment (Fig. 2) was obtained as a result of this analysis.

The evaluation detailed system to design strategies and proposals of management and conservation was focused in the assessment of the components of human pressure, indexes of fragility to finally evaluate vulnerability of the sub regions that compose the system REEESJC. Pressure consists of evaluation of the sub-indices of shocking, index population activity, index loss of naturalness and quality of water, in Figure 3, are observed each subscript values per unit, showing which exert greater influence and contribute to increase the pressure in each one.

The addition of the integration of weighted indices of pressure and fragility generated the vulnerability index, which clearly shows that the South is due to its natural characteristics as by the pressures exerted on these units, which requires immediate attention, especially C.d.2, C.d.4, units that show very high vulnerability and where the body of water is located. Also, in these units, most of the wetland vegetation, natural elements that maintain the wetland ecosystem and are home to the greatest number of species are located, which shows high vulnerability of C.d.5, D.f.6 and E.d.2 values and a small unit in southwest with medium vulnerability of E.d.5-unit value. Virtually, all the northwest areas of the REEESJ show a vulnerability rated as very low (A.a.1, C.d.3, C.a.3, C.a.4, C.c.3) and two units in the southeast of the reserve show values of very low and low, respectively (Fig. 4).

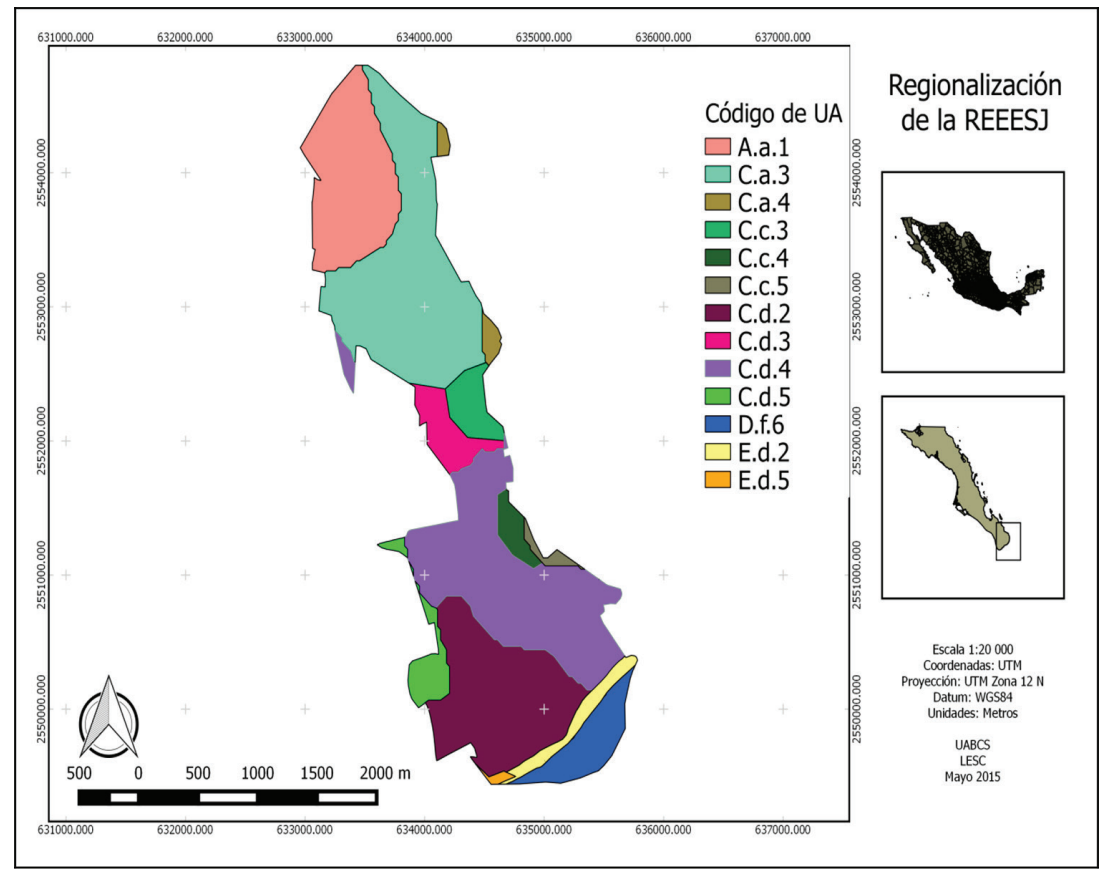

Figure 2: Map of the Environmental Units for the REEESJC. 

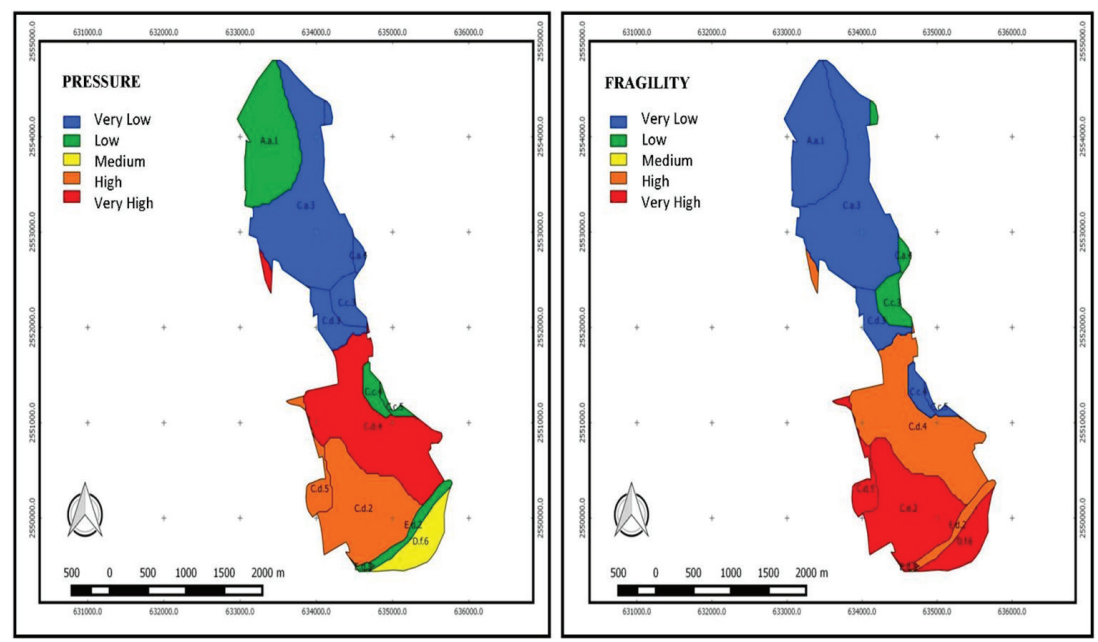

Figure 3: Assessments of Pressure and Fragility of the REEESJ.

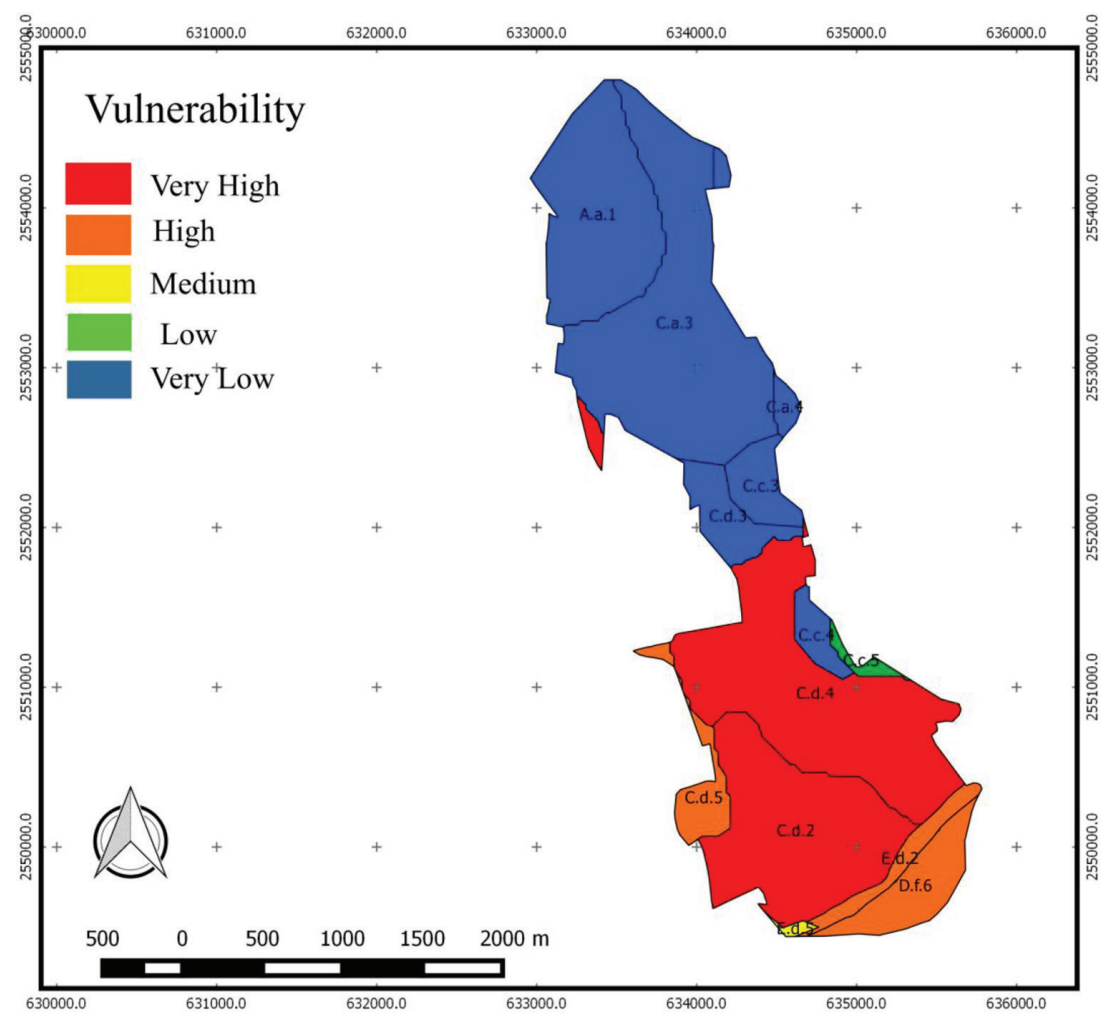

Figure 4: Vulnerability of each Environmental Unit of the REEESJ. 
The subscripts of fragmentation, biotic richness and physiography make up the fragility of the reserve (Fig. 3), where is observed that there is a decrease from North to South on the slope towards the units, C.d.4 C.d.5, C.d.2, where is the area of moisture and water body, and where the values of biotic wealth are higher, both species of land birds as aquatic, while from South to North an increase in the rate of fragmentation by number of paved and unpaved roads is observed with units A.a.1, C.a.3, C.c.3, C.c.5, C.d.2, C.d.3, C.d.4 and C.d.5 with the exception of the C.d.4 unit that has more road surface, highlighting the fragility of the wealth in this unit.

\section{DISCUSION}

The GIS methodological tool plays an important role since it allows to generate environmental units within the reserve, according to their base attributes (economic, social and environmental), as well as their characteristics and available information about those aspects that cause pressure or fragile items within this facilitating the management of a large amount of information and allows to select one that will make up the indicators and subscripts that give rise to maps synthesis of pressure, fragility and vulnerability within the REEESJC. It should be noted that the application of GIS in the present proposal identifies key issues for the implementation of the management plan and REEESJC administration. It is important to mention that in the last polygon modification of 2011, leaving the current surface of 766.7 hectares, and our calculation of the area of the polygon generated in the field and the GIS, gives us a total of 591.7 has, leaving a difference of 175 has missing the area. This makes a rectification of the total area of the reserve as well as a final and accurate georeferencing of the current polygon necessary, which would facilitate the work of surveillance and protection authorities.

On the other hand, vegetation types found within this area as well as play a role in the ecosystem are resources that can provide various services of supply, under a proper forest management already so that the wood of mesquite (Prosopis spp.) and other trees as well as the palm leaves and reeds can be used, which in turn would prevent the accumulation of dead leaves and dry cellulose, which is highly flammable and that on previous occasions. It is important to mention that to achieve a precise valuation of ecosystem in addition to considering services the scale of the area which we are working, it is necessary to count on a network of databases, complete, updated study that allows comparisons over time and between different sites. It would be recommended that future work establishes a network of databases of various sectors, social, economic, environmental etc., allowing to address his assessment of more comprehensive and complete, with interdisciplinary collaboration. However, this site due to its characteristics offers a unique opportunity to study together with scholars of social sciences and economics, as well as the natural sciences to provide a better understanding of the true significance of the site and give decision-makers, sufficient tools to take conservation and effective sustainable tourism measures.

Unfortunately, the recent status of the wetland has increased the vulnerability of the REEESJC and surrounding population, especially to dangerous environmental events, like eutrophication processes, pollution, and fires. The last 23th of April of 2017 some adjacent hotels to the wetland had to be evacuated because of a big fire (Fig. 5). The natural homeostasis of the integral ecosystem who possibilities to be a natural buffer to a natural disaster, has been lost for the geomorphology damage, producing a more fragile and vulnerable system.

As a resume of the Geomorphology changes in the last 15 years, Figure 6 shows the wetland original form in the last century, and the subsequent alteration and filling, generating the 


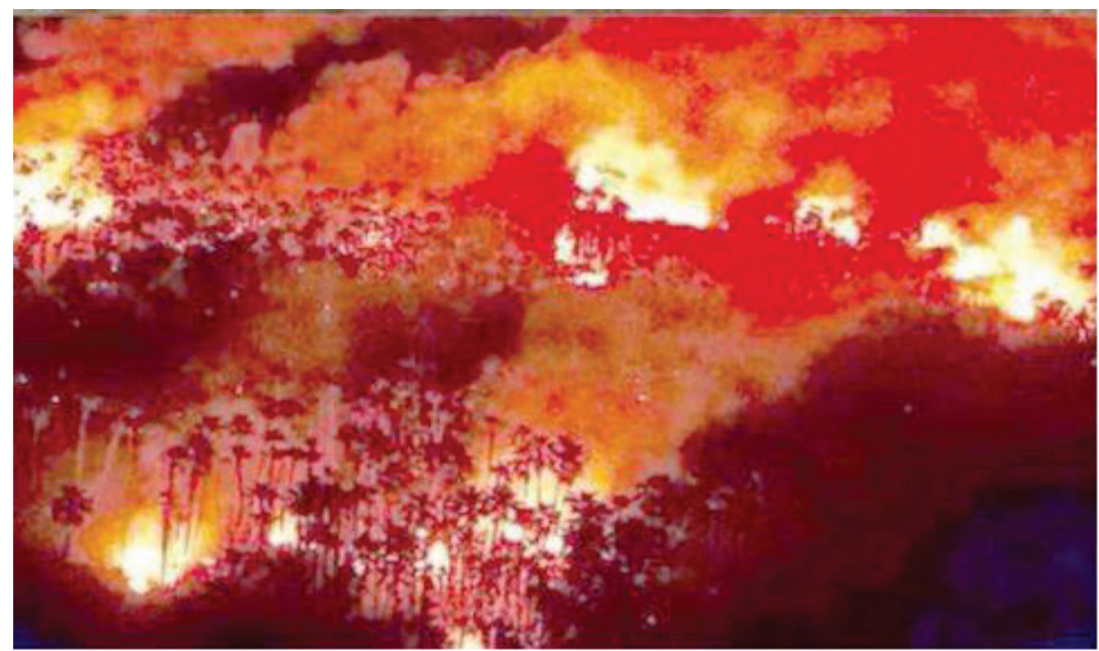

Figure 5: 23th of April of 2017, fire at the REEESJC (source, Sudcaliforniano 24/04/17, [15])

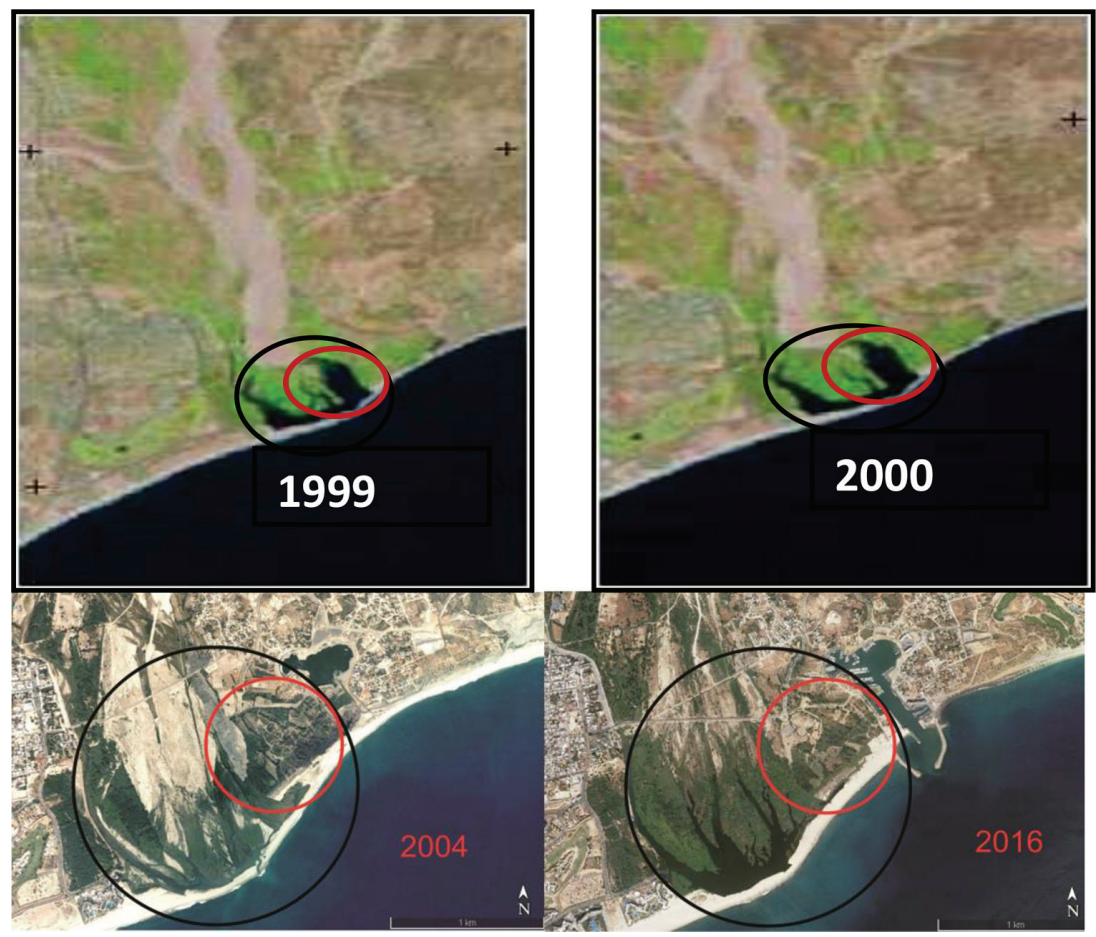

Figure 6: Changes in the geomorphology of the wetland from 2009 to 2016.

disappearing of the Northern arm of the wetland by human land use change, producing a big damage on the ecosystem services provided by the REEESJC. Integral determinations of fragility, pressure, and final evaluation of vulnerability, allow to know the current state of the system, becoming an important tool for the decision makers for the generation of program 
management with an important restoration component. Finally, considering the loss of original geomorphology, as a highly relevant ecosystem, it is important to implement an urgent study and Restauration Plan of the wetland of REEESJC, to prevent irremediable damages not just for the environment, also the tourism and the local population, with the increment for example of floods, fires, pollution, of this relevant ecosystem not just for Baja California Peninsula.

\section{Acknowledgements}

[We specially are grateful with M.S. Luz Armenta for her contribution with her study about a Management Proposal of REEESJC]

\section{References}

[1] Arizpe, O. \& Bermúdez, B., Prospective de the Natural Protected Areas of Los Cabos. En: Ganster, Arizpe, Ivanova, Los Cabos. Prospective for a Natural and Tourism Paradise. SDSU. 510pp, 2012.

[2] Secretaría de la Convención de Ramsar. Manual de la Convención de Ramsar: Guía a la Convención sobre los Humedales (Ramsar, Irán, 1971), $6^{a}$ ed., Secretaría de la Convención de Ramsar, Gland (Suiza), 2013

[3] U.A.B.C.S. Caracterización Ambiental de la Reserva Ecológica Estatal "Estero de San José". Unidad de Estudios Ambientales. PROMARCO. 149 p, 1996.

[4] OCDE. OECD Core Set of indicators for environmental performance reviews, a synthesis report by the group on the state of the environment (Environmental monograph no. 83). Organization for Economic Co-operation and Development, Paris. 37 p, 1993.

[5] Espejel, I., León, C., Fermán, J.L., Bocco, G., Rosete, F., Graizbord, B., Castellanos, A., Arizpe, O., Rodríguez, C., Planeación del uso del suelo en la región costera del Golfo de California y Pacífico Norte, México. En: Ribera-Arriaga E., G. Villalobos, I. Azuz-Adeath y F. Rosado May (eds.), El Manejo Costero de México. Universidad A. de Campeche, SEMARNAT, CETYS-Universidad, Universidad de Quintana Roo, 2004.

[6] Fermán, J.L., Ordenamiento Marino del Golfo de California. Thesis Doctoral. UABC, 2006.

[7] Arizpe, O., Fermán, J., Ribera, R., Ramírez, J. \& Rodríguez, R., Evaluation and land use planning process of a high population growth municipality: Los Cabos Mexico. WIT Transactions on Ecology and Environment, 108, pp. 87-98, 2008.

[8] González-Baheza, A. \& Arizpe, O., Vulnerability assessment for supporting sustainable coastal city development: a case study of La Paz, Mexico. Climate and Development, 2017. http://dx.doi.org/10.1080/17565529.2017.1291406

[9] Behrenfeld, M.J. \& Falkowski, P.G., Photosynthetic rates derived from satellite based chlorophyll concentration. Limnology and Oceanography, 42(1), pp. 1-20, 1997. https://doi.org/10.4319/lo.1997.42.1.0001

[10] Thieler, E.R. \& Hammar-Klose, E.S., National Assessment of Coastal Vulnerability to Sea-Level Rise: Preliminary Results for the U.S. Pacific Coast. U.S.G.S. Open-File Report. 178pp, 2000.

[11] Tallis, H.T., Ricketts, T., Guerry, A.D., Wood, S.A., Sharp, R., Nelson, E., Enanay, D., et al. VEST 2.2.0 User's Guide. The Natural Capital Project, Stanford. 323 pp, 2011.

[12] Arizpe, O.\& Arizpe, M., Prospective of the Natural Protected Areas of the south of Baja California Peninsula. WIT Transactions on Ecology and The Environment, 199, 2015.

[13] Armenta, L.F., Propuesta de programa de manejo para la reserva ecológica estatal Estero de San José. Tesis de Maestría en Ciencias. UABCS. 204 pp, 2015. 